\title{
European Corporate Governance: Harmonisation Through Knowledge Management?
}

\section{Gabriele G. S. Suder \& J. Michael Payte}

\section{Introduction}

The diversity of corporate governance systems internationally has been profoundly analysed in regard to international convergence (Rubach and Sebora, 1998), the conceptualising of national differences (O'Sullivan 2000), the research about two dichotomous models of AngloAmerican and European models, and by classifying the systemics of corporate governance along the activity or rigidity of labour, financial markets and ownership in particular. European models have fostered academic attention about national variations also through the studies of Cernat (2004), Dore (2000), Gerlach (2000), and Martin (1999) for Eastern Europe.

In this article, we acknowledge the importance of these works by using and complementing the conceptual framework with a convergence model that aims to use knowledge management (KM) concepts for the convergence of corporate governance on a European management scale. We examine both the academic and the institutional attempts to conceptualise a convergence in advanced capitalist economies. For instance, the OECD AdHoc Task Force on Corporate Governance developed a set of non-binding principles, elaborated in conjunction with member states, other international organizations and corporations. The principles were set to build upon past and recent experience, and to lay a basis that could assist parties in developing rigorous, possibly converging standards for publicly traded companies. However, these principles were not to substitute private sector 'best practice' principles; rather, the initiative attempts to enhance synergy between macroeconomic and structural guidelines (i.e. the overall business environment and fixed governmental settings). At the same time, the European KM Forum is debating a common European framework reflecting an interdisciplinary consensus towards convergence issues (EKMF 2001: 8). The similarity and possible cohesion between the two debates is striking in the clustering of objectives obtainable as results, and the usefulness of the KM approach to convergence concepts on European corporate governance level, in regards to usability. Key characteristics of the KM approach are simplicity, recognition, convenience, availability, evolution, quality of network, focus on ergonomics, transparency and dissemination of results, and a knowledge based non-technological solution method for convergence. If we compare the European Union to a KM organized corporation, then we can attempt to benefit from KM determinants: Explicit knowledge offers great "potential for value creation because of its replicability potential" (Grant in Despres and Chauvel 2000: 33). We argue that national corporate governance models contain this explicit knowledge and therefore a high potential for convergence along the above-mentioned key characteristics taken from KM, that allow us to develop a European convergence model and to research the methodology of value integration.

Over the past two decades or so, multinational corporations (MNCs) that have emerged as major forces in the global economy have been the origin of important changes in the corporate governance principles at national and international level (see the works of Fukao 1995). In particular, this is due, not only to the derivatives crisis including Barings, Metallgesellschaft, Procter \& Gamble and Sumitomo, but also the Asian financial crisis of 1997; 
the end of the bubble economy with the crises of Cendant, Enron, WorldCom, Parmalat; director compensation scandals like that at the New York Stock Exchange, Tyco, GE, ABB, Vivendi, Mannesmann, and the consequent 2002 American Sarbanes- Oxley Act, which led to the establishing of new national regulatory principles such as The Public Company Accounting Oversight Board (PCAOB) in the US, as well as at NYSE and NASDAQ (Holmstrom and Kaplan 2003; Baums and Scott 2003). The European Union (EU) is subject to an evolution of national corporate governance principles that have given rise to heated debate about cross-national diversity and possible standards on an EU level. Will there in fact be twentyseven different and independent supervisory boards set up? The benefit of convergence will be discussed.

Corporate governance frameworks are elaborated from legal, regulatory and institutional environments of a large economic context in which the MNC works. They are also based on business ethics and the responsible business image that the corporation advances in the long term (OECD 1999). In this paper, a selective comparative study sheds light on the business environment that is at the origin of European corporate governance models, and their separation between ownership and control, the legal sets behind corporate law and corporate finance, a comparison of the role of the board of directors, and executive compensation. From this comparative approach, we conclude whether the trans-nationality of knowledge management in MNCs is effectively a driving force that has the potential for the convergence of the models existent in the European market, given that the EU creates a harmonized, common set of policies and procedures in numerous fields that crucially determine the modus operanti of corporations. The European Commission's 'Modernizing Company Law and Enhancing Corporate Governance in the European Union' plan, the European Corporate Governance Forum, and the continuous, - if for some, still hesitant dialogue, are signs that future harmonization can be envisaged on a pan-European regulatory level. As this paper is being written in the mid 2000s, a form of harmonization and convergence is emerging between the EU and the US Sarbanes Oxley Act as Frits Bolkestein, EU Commissioner for the Single Market and William McDonough, Chairman of the US Public Company Accounting Oversight Board (PCAOB) have begun to work on a "constructive, cooperative way forward" that will permit joint co-operation on enforcement (Financial Times 2004: 9). This would have been unthinkable not so long ago.

The analysis is organized as follows: The first section presents a definition of corporate governance and related international framework information. We make reference to the lessons that can be learned in research from the recent corporate governance scandals in Europe. We also expand on the current theoretical literature of internationalization and harmonization. This is followed by a second section with a brief review of empirical work on European corporate governance models that allow us to classify the prevailing models and to elaborate, by way of analogy, an integrating model. The third section defines the variables necessary for convergence on EU level and an EU model development. This section then studies the theoretical impact of trans-national knowledge management; the discussion is held at a theoretical level. We offer a proposition for a model that uses KM theory in order to advance the understanding of the challenges that convergence embed for management and organizations. The last section offers some concluding remarks that underpin our crossdisciplinary approach that is strongly inspired by actor-centered institutionalism (Scharpf 1997) in that we believe in the strong mutual impact of the relationship between institutions and corporations.

Through systemised modelling of corporate governance approaches, we analyze the theoretical setting available and challenge the agency-theory regarding the theory's premise that there are just two stakeholders - managers and shareholders. The common knowledge of corporate governance models was created separately through tacit and explicit actors and divergent foundations in the past. However, dynamic interaction over time affects the orientation of the CG model that evolves along the co-evolution of the corporate environment ( McKelvey 1999) and inside the organisation (Spender 1996) through what can be labelled a community of practice (Wenger 1998) that deploys codes of best practice with a replicability potential. A model and methodology for a European convergence harmonization 
are developed that are based on Spender and Grant's theorem that an organization's primary source of value creation is its efficient usability of knowledge.

This article investigates, hence, the link that can be established between corporate governance convergence and KM methodology, and its impact on corporate competitive advantage: Does convergence of models on a European level potentially inhibit or foster corporate reactivity as referred to by Scharpf? Does the harmonized corporate governance model (CGM) have the potential to allow knowledge management the ability to create, transfer and integrate value through the dissemination of best practice and community of practice- inspired implementation?

\section{Corporate Governance Theory and Internationalisation}

The study of internationalisation focuses on of corporate governance analysis, mainly on agency-theory and its impact on convergence towards an Anglo-Saxon system. We challenge this theory and develop a proposition for a European scale model that is not exclusive to this area in its potential implication, but founded in the particular diversity of the European management and organisations that provide the ideal playing field for the forces of regional harmonization along the actor-centred institutionalism known from sociology. We believe in value creation through diversity, and challenge the label of 'fragmentation' that implies negativity. As such, this article does not attempt to discuss either the impact of sociology or to examine institutional configurations that are discussed in the research of Aguilera and Jackson (2003) and others, but rather to propose a facilitating model for convergence.

The substantial direct investment in foreign countries and the deeper and wider integration of the EU, imply an active management of offshore assets and not just holding them as a passive financial portfolio. The Single Market compels European management integration of operations located in different countries, in a competitive game that embraces multiple markets and multiple strategic options. Internationalisation generally comes with currency fluctuation and exchange risk, and economic performance measured in multiple currencies. This risk is superfluous in the Euro-zone countries but persists with all other European countries. This defines the company determination of governance structures and mechanisms that serve and control organizational functioning. The MNC that follow the example of the first European colonial trading companies in the $16^{\text {th }}$ and $17^{\text {th }}$ centuries (Muchlinsky 1995) are explained in their existence by the theory, established by Hymer (1970a; 1970b). They exploit comparative advantages by going abroad, at the same time internationally integrating operations. Recent theory states that in the case of transactional market failure, the corporation must internalize markets to retain monopolistic advantages across borders (Dunning 1988). Rugman and Verbeke (2004) demonstrate that the economically integrated region is, in this context, the main market for MNCs, stating that "The regional concentration of sales has important implications for various strands of mainstream IB [International Business] research, as well as for the broader managerial debate on the design of optimal strategies and governance structures for MNEs", i.e. corporations that produce and/or distribute products/services abroad (Rugman and Verbeke 2004: 3). The costs of international operation and of Europeanisation must be offset by these advantages, and the extension of Coase's microeconomic theory (the firm as a boundary with internalised exchanges) to the larger business environment, leads us to argue that in the integrated market, corporations also re-allocate governance, by adopting international or trans-national strategies: Levitt (1983) is probably one of the strongest advocates of the standardised approach to international business operations, that have been adjusted by modern IB research recognising that, MNCs answer to and exploit the diversity in national structures; while Prahalat, C.K.; Doz, Y. L. (1987) and others explore the issues of local responsiveness, and develop the internalising model of foreign expansion (Buckley and Casson 1976; Rugman 1981). Depending on the strategy adopted by the corporation, it benefits from differing economic, social and regulatory business environments. 
Organisational complexity in the particularly diverse European market calls for the study of the governance mechanisms of corporate governance (for important literature reviews, see Pettigrew 1992; Huse 2000). We need to go further than the analysis of the control of the executive and the protection of the shareholder. If companies need to manage complex demands across barriers of distance, time, language and cultures, they also need to reply to the opportunity or threat that harmonisation on European level may pose. This paper, therefore, explores the relationship between a selection of harmonisation and convergence issues with regard to reporting and corporate governance in the EU, thus challenging the agency-theory's narrow premise that there are just two participants - managers and shareholders (Dalton, Daily, Elstrand and Johnson 1998; Shleifer and Vishney 1997; Dalton, Daily, Certo and Roengoitya 2003) and their attempt to bring each other's interests in line (Walsh and Seward 1990). We maintain that there are more than just two sets of participants. These include, the non-management employees, the customers of the corporation (which is the reason for the corporation's continued existence) and the overall environment in which the corporation operates. We also include the community at large in which the corporation operates. This is particularly significant what with management pursuing a course of continued existence and improved performance, such as better and more competitive products, improved financial performance, production or product enhancements that propel the corporations forward rather than "strip mining" the corporations' assets and goodwill. We support the thesis that corporate governance traditionally focuses on the control of the executive by the board and the stockholders, "but also the contractual covenants and insolvency powers of debt holders, the commitments entered into with employees and customers and suppliers, the regulatory issues by governmental agencies, and the statues enacted by parliamentary bodies" (Baums and Scott 2003: 5). This comprises the broader macroeconomic context including competitive conditions in the many markets in which an MNC operates. For instance, the International Organization of Securities Commission, in 2000, recommended accounting standards to be used by multinational issuers for financial statements for cross-border offerings and listings. The European Commission proposed a regulation in February 2001 to require listed companies to use international accounting standards by 2005 in consolidated statements. This move is a strong sign of the coordination that was enhanced over the past five years, including a supervisory system "to guarantee representation of the full European interest" (EFRAG proposal (www.iasplus.com)). We argue that the European Union will realise a convergence of corporate governance along the lines known by the setting of international accounting standards, embedded in the particular diversity and along the developments that KM convergence will open up.

A further school of corporate governance theory, the resource dependence theory, emphasises the role of the executive in the enhancing of organisational functioning, its position in the competitive environment and strategy (Johnson et. al. 1996; Dalton, Daily, Johnson and Ellstrand 1999). Contributions to the modes of functioning and reporting are herein dependent on the access of resources that can be furnished by directors of the company, mainly from the outside. This theory attempts to complement the agency-theory, just as the stewardship theory (Davis, Schoorman and Donaldson 1997,) does, by reinforcing the attention given to the mutual interests between executives and shareholders, according to the theory that executives will generally strive to improve their long-term image by improving financial performance indicators, which profits shareholders' return (Baysinger and Hoskisson 1990). Their potential conflict of interest as studies by Jensen and Werner (1988), Daily and Johnson (1997), mainly help to explain the succession process (Shen and Canella 2002), while further studies permit conceptualisation of class hegemony, the legalistic theory, and signalling theory and compensation criteria. Agency-theory is, however, the dominant framework used for the analysis of corporate governance models, as developed by Berle and Mean in 1932. As the theory makes assumptions that were challenged by an important body of theory, we turn to the analysis of research of the corporate environment that can explain a multitheoretical view as defended by Lynall, Golden and Hillman (2003). Our approach is to shed light on corporate governance models in Europe. We categorize systems on the basis of criteria that have become recently available from the current governance scandals, and that call for a study of the possible harmonisation, on EU level, of either corporate governance models, or guidelines concerning best practice. 


\section{Systemic Future of Corporate Governance in Europe}

Institutional and corporate organisations gain their legitimacy and image from sources of performance that potentially homogenise the process of reporting; this interaction was largely researched by DiMaggion and Powell (1983). It can be complemented by the fundamental research concerning the role of KM that states that a high stock and diversity of knowledge supports a high performance potential for the multinational economy. In both disciplines, it is the internationalisation, the sophistication of the environment, and bottlenecks in legitimacy and effectiveness that drive a convergence of knowledge, in order to (1) develop economics of ideas (Despres and Chauvel 2000, pp. 9-15), (2) cognitive science to understand how people function herein, and (3) best practices satisfying unique demands to 'customize' legitimacy and control it.

The systemic failure of public trust in the corporate sector has been led by a combination of collusion, conspiracy, connivance, incompetence and at the very least a culture of 'benign neglect' by the very groups responsible for the checks and balances in the business community. In the 1990's we find the seeds of this crisis being sown by the US Securities and Exchange Commission aided and abetted, by changes in the US tax code and the US Internal Revenue Service. This began with the alteration of the whole system of remuneration and financial rewards for corporate executives that were supposedly being "reformed" through the adoption of the new mantra that executive performance must be more closely tied and directly reflects the performance of the corporation. New comprehensive disclosure rules were mandated by the SEC in the Executive Compensations Disclosure Rules of 1992. While these rules and disclosures were certainly a good thing, the reforms did not end there because not only did these new rules require comprehensive disclosure about executive pay, but this event was then abetted by changes in the tax laws of the US whereby a cap on the deductibility of executive payments not directly related to performance was instituted (Daily and Dalton, Canella 2003). This prompted the introduction and explosion of executive stock option plans, which then directly led managements to the extremes of manipulation of the short term, quarter-to-quarter financial reports. For example, the false balance sheets and resulting income statements of Parmalat subsidiaries in the most recent wave of European scandals were carefully adjusted to make sense of the group's overall financial position. The black hole in Parmalat's balance sheet has now been estimated to be in excess of $\$ 13$ billon. On 29 December 2005, Parmalat's shares were suspended indefinitely on the Milan Stock Exchange. Parmalat used the Cayman Islands, the leading off-shore tax haven, to raise more than US\$1 billion; "Milan prosecutors asked judges to indict 29 individuals and three companies on charges related to the alleged fraud" (Wall Street Journal 2004). In this case, Bank of America, Deloitte \& Touche and Grant Thornton are among the firms which are involved in the disappearance of $€ 10$ billion from Parmalat's books. America's Securities and Exchange Commission accused Parmalat of misleading bond investors in the biggest financial fraud case in the history of Italy. Financial fraud cases show that with greater globalisation of the world's capital market, the inadequacies of both the American and European regulators, such as the SEC and the various national regulators in Europe, are revealed. The current phenomenon began with the derivatives crisis including Barings, Metallgesellschaft, Procter \& Gamble, and Sumitomo (Halpern 2000), but also the Asian financial crisis of 1997, the end of the bubble economy with the crises of Cendant, Enron, WorldCom, director compensation scandals like that at the New York Stock Exchange, Tyco, GE, ABB, Vivendi, Mannesmann, which led to the subsequent 2002 US 'Sarbanes-Oxley Act', the establishing of new national regulatory principles such as 'The Public Company Accounting Oversight Board' (PCAOB), as well as greater oversight at the NYSE and NASDAQ (see Baums and Scott 2003). Enron's collapse seemed to herald a wave of corporate malfeasance that took in US Corporate Governance such as World Com, Tyco, Adelphia and many others. While the issues of failure remain an important set of research, in the context of this article, we focus on the wave of knowledge. The knowledge that was heralded makes it clear to us that the current body of analysis need to be complemented, not only in regard to work about the possible setting of 
harmonised guidance, but also about the management and transfer of corporate governance knowledge on a European scale.

The Parmalat case, followed by Ahold, Adecco, and now Shell, is not isolated in the European business landscape, but at the same time, the problem cannot be generalized. Despite the existence of a single market for goods, services and capital, Europe projects a very diverse picture in the functioning of corporate governance mechanisms (Aguilera and Jackson 2003; Berglöf 2000; O'Sullivan 2000; Weil, Gotschal, Manges 2002). These differences are due to variations in shareholding structures and different social and economic traditions. With the single market measures gradually achieving their effect and the market playing a bigger role in corporate control, a gradual convergence in corporate governance standards is projected.

Improvements in corporate governance practices (best practices) could increase Europe's competitiveness and enhance the attractiveness of its equity markets. Ethical responsibility and stronger internal controls are defences against future Parmalat style scandals. A successful convergence through knowledge management and transfer on European scale has the potential to increase the economics of ideas and enhance corporate legitimacy. This suggests that a convergence model has to be developed that satisfies KM criteria, and that is based on the diversity found in the theoretical and practical settings.

The previous discussion highlights essential requirements faced by the convergence and transfer of corporate governance knowledge. It follows that we can categorise the empirical and conceptual works on European corporate governance models as presented in the literature review. Corporate governance has been the reserve of the national law systems of each member state (Van der Elst 2002; EIRO 2002). This is the foundation of a variety of systems that can very broadly be classified as the Anglo-Saxon, Nordic and the German systems (La Porta et. al. 1998). Tables 1 to 3 present a categorising of European states by 'legal traditions', 'corporate law' and 'corporate finance' that is indicative, but not exhaustive. These categorisations allow us to understand not only the diversity, but also the possible convergence potential that particular corporate governance models in Europe may represent.

Table 1: Indicative Categorising of European states by Legal Traditions

\begin{tabular}{|l|lll|}
\hline \multicolumn{4}{|c|}{ Legal Tradition } \\
\hline Common Law & \multicolumn{3}{|c|}{ Civil Law } \\
\hline \multirow{3}{*}{ Ireland } & French & Scandinavian & German \\
UK & Belgium/Luxemburg & Denmark & Austria \\
& France & Finland & Germany \\
& Greece & Sweden & \\
& Italy & & \\
& Portugal & & \\
& Spain & & \\
\hline
\end{tabular}

Adapted from Emmons and Schmid (2000) 
Table 2: Indicative Categorising of European states by Corporate Law

\begin{tabular}{|l|ll|}
\hline Corporate Law & \multicolumn{2}{|c|}{ Shareholder versus Stakeholder focus } \\
\hline Company Based & Enterprise/Stakeholder based & \\
\hline Shareholder & Trade Unions / & Co-determination \\
& Collective Bargaining & \\
Ireland & France & Austria \\
UK & Greece & Belgium \\
& Italy & Denmark \\
& Portugal & Finland \\
& Spain & Germany \\
& & Luxemburg \\
& & Netherlands \\
& & Sweden \\
\hline
\end{tabular}

Adapted from Berglöf (2000); EIRO (2002)

Table 3: Indicative Categorising of European states by Corporate Finance

\section{Corporate Finance}

\begin{tabular}{|l|ll}
\hline Outsider & Insider & \\
\hline & Bank/State & Bank/Family \\
UK & France & Belgium \\
Ireland & Greece & Denmark \\
Finland & Germany & Sweden \\
& Portugal & Italy \\
& Spain & Netherlands
\end{tabular}

Adapted from Berglöf (2000); EIRO (2002); Walter (2002)

Table 4: European Best Practice Codes (selected)

\begin{tabular}{|l|llll|}
\hline & UK & France & Germany & Italy \\
\hline $\begin{array}{l}\text { Board } \\
\text { independence }\end{array}$ & $\begin{array}{l}1 / 3 \text { non-executive } \\
\text { directors (NED's) } \\
\text { majority } \\
\text { independent }\end{array}$ & $\begin{array}{l}\text { Majority } \\
\text { independent }\end{array}$ & $\begin{array}{l}\text { Unspecified } \\
\text { number of } \\
\text { independents }\end{array}$ & $\begin{array}{l}\text { Adequate } \\
\text { number } \\
\text { independent }\end{array}$ \\
$\begin{array}{l}\text { Separate } \\
\text { Chairman/CEO }\end{array}$ & $\begin{array}{l}\text { Split } \\
\text { recommended }\end{array}$ & Do either & $\begin{array}{l}\text { Required by law } \\
\text { for larger } \\
\text { companies }\end{array}$ & No \\
$\begin{array}{l}\text { Audit committee } \\
\text { composition }\end{array}$ & $\begin{array}{l}\text { At least 3 NEDs, at } \\
\text { least 2 of them } \\
\text { independent }\end{array}$ & $\begin{array}{l}2 / 3 \\
\text { independent }\end{array}$ & $\begin{array}{l}\text { Minimal } \\
\text { guidance }\end{array}$ & All NED's \\
$\begin{array}{l}\text { Executive pay } \\
\text { disclosure }\end{array}$ & Yes & Yes & Encouraged & No \\
\hline
\end{tabular}

The Economist (2004a: 51) 
We have found that in Legal Tradition, it is useful to distinguish between Common Law and Civil Law foundations of governance models; in the latter category three dominant streams of thought emerge and are classified as French, Scandinavian and German. Legal traditions and systems, according to Weil (2002), La Porta et al. (1998), determine the rights and obligations that rule the government principles in regard to investors, and therefore the shape of corporate finance, reporting, and best practices as categorised in Table 4.

In Corporate Law, we found tendencies relating to a 'Shareholder' versus 'Stakeholder' focus, depending on the model. It is of particular interest to note that in the category Trade Unions / Collective Bargaining or Co-determination, we find that the above mentioned Scandinavian and German stream are considerably coherent. Then the distinction in Corporate Finance and reporting mechanisms that found a focus on either Outsider or Insider mechanisms, presents, for example, Germany and Finland in different categories than the countries that appeared to subscribe to a similar governance model in the two prior tables. Consequently, there is the potential for the introduction of a common denominator.

\section{Managing Convergence and Knowledge Transfer: Discussion and Assessment}

The diversity of models defines the variables necessary to converge on an EU level if harmonisation is to be achieved, and an EU model developed. Three key capabilities of knowledge management in MNEs are sensing, responding, and implementing. On an organisational level, these translate into knowledge recognition (explicit and tacit), knowledge value creation and convergence, and knowledge integration. It has been argued that for mature MNEs, the development of valuable skills can occur at any location of operation, at home or in foreign subsidiaries (Berkinshaw and Hood 1998; Gupta and Govindarajan 2000, Anderson, Forsgren and Holm 2002). It can be noted that given the diversity of European models, and the categories that can be established thereof, a European MNE can exploit location advantages in corporate governance issues that are potentially harmonised by the EU. The harmonisation of corporate governance models along the knowledge-based theory allows for the tackling of uncertainty solutions if types of knowledge relate to the types of uncertainty in corporate governance.

Diagram 1: Convergence Modelling for European Corporate Governance

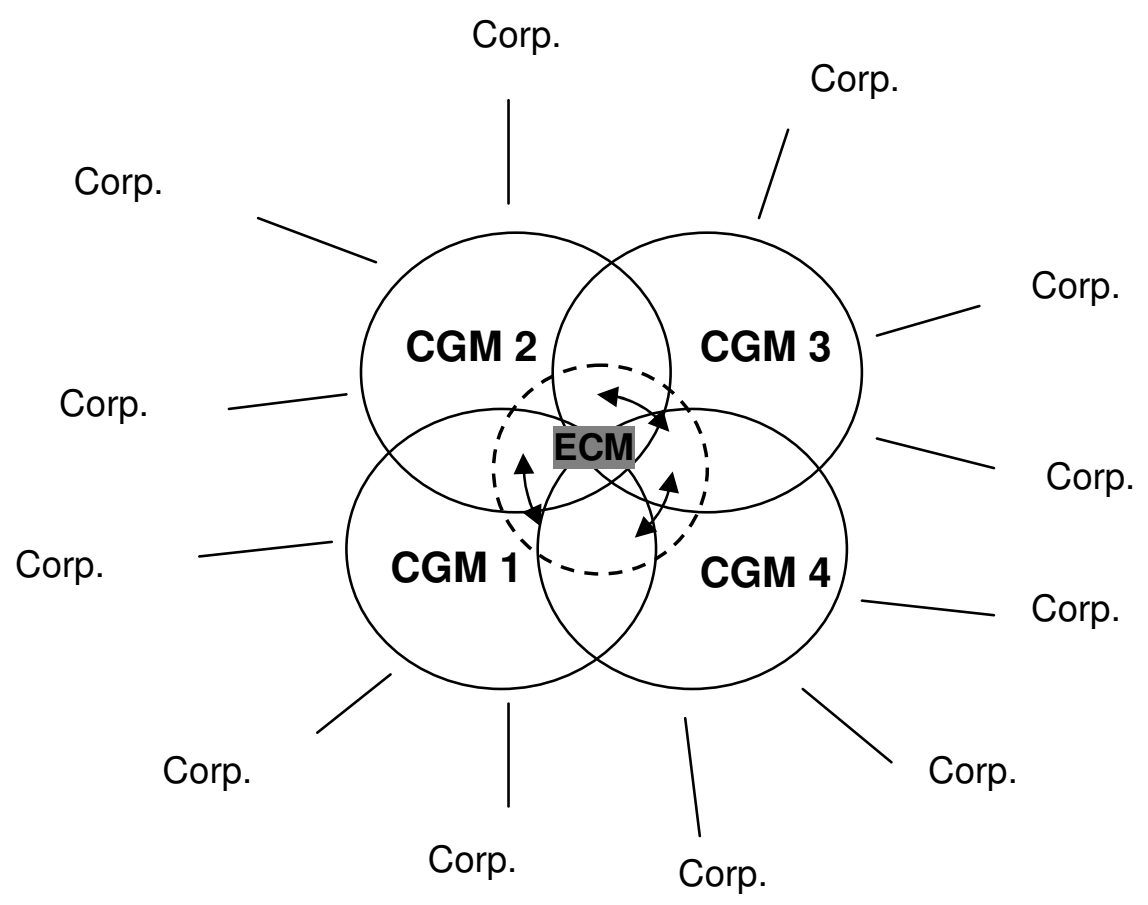

CGM: Corporate Governance Models ECM: European Convergence Model Corp.: Corporation 
In Diagram 1, a Convergence Modelling for European Corporate Governance is conceptualised. The number of CGMs (CGM1, CGM 2...) is arbitrary and depends on the categorising that is applied, by legal system, financial system, and so on, as represented above in Tables 1 to 4. This means that we are not restricting the number of national models in the European market to four; but the figure is useful in illustration of the simplicity and comprehensiveness of the model only.

To each national model, a quantity of corporations or their subsidiaries subscribe. If a European convergence is to be based on knowledge transfer and integration, then this ECM will allow the dissemination of what is most recognised, useable, available, simple and flexible in each of the currently distinguished models. Corporations can then subscribe to the model (Diagram 1); this would serve the corporations and institutions in the Europeanised business reality. This assumption facilitates the implementation of continuous reporting, controlling and monitoring of multi-structured corporations.

It was found that the collapse of public trust in the corporate sector meant that, potentially, the compliant and moribund members of the Boards of Directors were unable to challenge charismatic chief executives in the mature European economy. The collusion of the corporation's commercial and investment bankers created hidden and ticking time-bombs in special purpose vehicles (SPVs) both on-shore and off-shore which were susceptible to exploding when the pressure for financial disclosure exceeded the maximum sustainable level.

Securities analysts following the companies, (by reason of change in their mandate, by the managements of the commercial and investment banks, from reasonably independent and accurate analysts and reporters of a corporation's outlook) changed into agents of new business for the corporate finance departments of the investments banks; taking their specialized knowledge with them. Credit agencies and their analysts were virtually hamstrung in their ability to analyse corporate financial statements and reports. The corporate governance scandals also showed that there is a traditionally benign shareholder culture dominated by institutional managers that have only recently begun to find an activist voice. This needs an organisational stimulus to transfer knowledge and integrate it into control structures.

Integration and implementation are based on coordination that needs to focus on the arrangement of what is the most feasible to use in the European corporate environment, through the knowledge transfer that takes place in the ECM, Diagram 1. Whether the knowledge is explicit or tacit, corporations and public policy actors face a complex process, in which separate models are specialised and retain specialist knowledge, comparable to Grant's intra-company model (Grant 1996). The complexity is then the dependent variable of order creation along the concepts studies by Lewin (Lewin 1993).

While published financial statements are today virtually opaque and impenetrable to even the most sophisticated financial experts, as well as to the last line of defence, the credit rating agencies and their analysts, an efficient European model can be based on the dissemination of what is most recognised, useable, available, simple and flexible in each current model that can be distinguished. The corporations that subscribe to these models are identified in Diagram 1. From the analysis of these models arises a common knowledge of corporate governance that was created separately in the past, and that will be a dynamic for interaction between public policy and the corporate sector over time. This dynamic and interaction affects the orientation of the convergence model that evolves along the co-evolution of the corporate environment (McKelvey 1999) and inside the organisation (Spender 1996) through what can be labelled a community of practice (Wenger 1998) that deploys codes of best practice.

Looking ahead, the clean-up of corporate governance scandals has begun. The issue of strengthening the resolve and authority of the members of the Boards of Directors is at first sight mandating the expansion and greater authority of "non-executive" members of the 
Boards of Directors. "It has been shown that a well-organised and determined group of nonexecutive members of a Board of Directors can in fact be a powerful force to improve corporate governance by reining in over-mighty chief executives" (The Economist 2004b). The traditional approach to appointing members to Boards of Directors has been for the chief executive to hand-pick the strongest supports from inside a firm and then fill in with their "golfing" pals for the remainder of the positions. Improvements in accounting and auditing have now received a "kick-start" both in Europe and the US, first through the "knee-jerk reaction" legislation known as Sarbanes-Oxley passed by the US Congress in 2002 to strengthen and repair weaknesses in corporate-governance, auditing and accountability. These changes, as well as the Parmalat, Ahold, Adecco and Shell scandals in Europe have given the necessary boost required for European action. Now a key question here is the coordination/harmonisation between the US and Europe as well as across the incumbent pre200415 member countries and the issue of how to include the newest 12 members that are undoubtedly technologically and methodologically behind current practices. The US has established the Public Company Accounting Oversight Board (PCAOB), the UK may not be far behind and there will surely be more to come. Warnings are already being posted by such organisations, such as the UK's Institute of Chartered Accountants, about how overreaction to recent scandals could lead to huge increases in red tape and higher costs.

A key concern is whether the cures being proposed as well as the admitted need of coordination/harmonisation will create a straight jacketed environment so structured that creativity and inventiveness of the modern corporation will be stifled. Are we unleashing a new and counterproductive chain of events that will also operate under "The Theory of Unintended Consequences" causing the pendulum to swing massively so far the other way that it will create a period of stagnation just when the world economy needs the maximum of creativity to stimulate growth? What is the right balance that will "keep the game straight and honest" but not saddle it with so much red tape that we are inadvertently starving the engines of growth and progress. Are we going to create so much regulatory co-operation and harmonisation as to create a new and un-thought of form of systemic risk in the corporate world? How are we going to institute "best practices" reaching both sides of the Atlantic as well across the current 27 EU members? How do we maintain creativity and diversity without sinking to the lowest common denominator or the blandness of averaging across all these dynamic cultures? After all, the basic premise of the creation of the EU is the stimulation of the free flow of goods, people and capital and to create greater economic stability and growth and a better life for its citizens.

Clearly, we must have improvements in the technical knowledge and authority of the oversight committees on the Boards of Directors; clearly, we must have some means of rebalancing the theoretical checks and balances of our economic systems.

"Opening the Doors of the Boardroom" the clarion call "to end the 'magic circle' of white middle-aged men" otherwise known as the 'old boy network' of cronyism that has dominated boardrooms across the Anglo-American-European corporate environment. This is the essence from a report commissioned by the UK's Department of Trade and Industry as reported by Stephen Bubb in The Times (26 April, 2004: 27). A key element of the report cites an increasing amount of creativity, effectiveness, enhanced corporate decision making and greater oversight through the opening up of corporate governance to a much greater range of different backgrounds and experiences. This replaces the traditional, exclusive corporate friendship and personal contact style of recruitment. The first steps in establishing this concept was the UK government's establishment of an appointments process though their Public Appointments Unit; this concept could now be greatly expanded into the commercial sector. Something of this nature could easily be replicated across the European corporate landscape, not only opening up corporate governance to wider segments of each individual member state, but the opening up of availabilities and appointments across the EU for greater cross cultural board interface and membership. This is a key model that can be used to enhance corporate governance through effective cultural harmonisation, knowledge transfer and knowledge management and fits very well into the model represented in Diagram 1 with this set of cross-cultural board members fitting into the Corporate 
Governance Models and communicating ideas and concepts through the Knowledge Transfer of the European Convergence Model. This is illustrated in Diagram 2 below.

Diagram 2: Convergence Modelling for European Corporate Governance

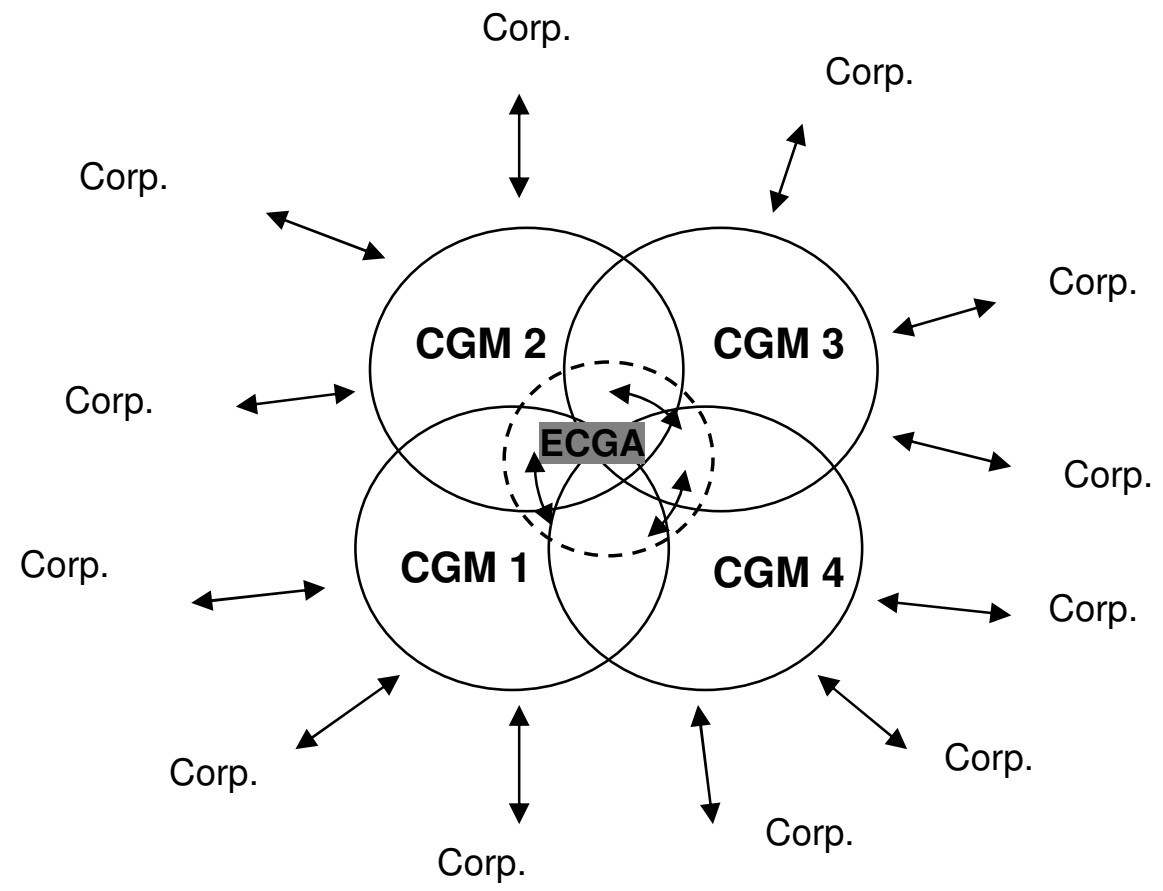

EU1, 2, 3, 4: EU Member States

ECGA: European Corporate Governance Appointments Corp.: Corporation

$\longleftrightarrow$ Knowledge Transfer: A request for Non-Executive

Directors from Corps. To ECGA, response and

recommendations in return

This raises the bar of intellectual capacity at the corporate board level by opening the doors across all these dynamic cultures to a broader spectrum of highly talented, competent and committed individuals rather than risking the alternative of "sinking to the lowest common denominator or the blandness of averaging", as referenced above. This gives the independence of board members the authority of oversight that can recalibrate the system of checks and balances designed to protect the international market system by introducing enhanced technical knowledge, innovation and creativity at a time of great need to thrust industry forward. Establishing a cross industry mechanism such as this model, operated and staffed by a broad range of participants from the European corporate community to assist in sourcing, vetting and matching individuals, interests and skills with corporate governing boards would be a giant stride forward without creating another Brussels based governmental bureaucracy surely to spew out reams and reams of rules, regulations, guidelines and directives. This would be a cross- European industry based initiative with the understanding of the needs and requirements of corporations in mind and it would be a strong signal to government officials, regulatory authorities, investors, analysts, employees, customers and their communities, that industry was in fact serious about enhanced corporate governance and restoring public confidence in the corporate community.

\section{Conclusion}

From the start, we supported the thesis that corporate governance focuses traditionally on the control of the executive by the board and the stockholders, "but also the contractual covenants and insolvency powers of debt holders, the commitments entered into with 
employees and customers and suppliers, the regulations issues by governmental agencies, and the statues enacted by parliamentary bodies" (Baums and Scott 2003: 5). The research and conceptualising that was used for this article have allowed us to establish an important link between the study of corporate governance solutions and the lessons that can be learned from KM for a harmonisation of models that report and control corporations that strive for efficiency in the international Europeanised environment.

It has been noted that three simplifying assumptions have blocked progress with the transnational processes: (1) that subsidiaries are symmetrical ("the United Nations syndrome"); (2) that HQ-subsidiary relationship is based on pattern of dependence / independence; and (3) that corporate management exercises control uniformly. The recent cases of corporate scandals and the increasingly important body of research in the field argue that we evolve from symmetry to differentiation in the European strategy model. If this is so, then each unit has its own distinct role to play in corporate governance and it subscribes to a divergent corporate governance model. Public policy, taken as a response to the Europeanisation of the economic and corporate realities, needs to respond to a harmonisation of standards or guidelines. If corporations and their subsidiaries and affiliates move from dependence or independence to inter-dependence, this is probably most likely through inter-unit integration mechanisms in business sectors. If however Europeanisation leads from uni-dimensional control to differentiated control, then it is important to make better use of the social control mechanism. The transfer of specialised knowledge from each CGM into the CM necessitates the integration of available, usable, simple, and dynamic knowledge.

In this article, we have elaborated (a) a possible ECM, and (b) discussed the usability of KM to the harmonisation of such value in the European framework in which we followed an actorcentred institutionalism (Scharpf 1997). We believe in the strong mutual impact of the relationship between institutions and corporations. Yet, our concerns are raised as to how these changes in corporate governance will impact corporate productivity, as well as corporate competitive advantage given asymmetrical adoption and implementation programs and time tables. Also, will a convergence of models on a pan-European basis level the field and will this convergence inhibit or foster corporate reactivity and momentum. At this time, it is still too early to analyse or project where the balance lies between enhanced corporate governance accompanied with accurate reporting versus some overly ambitious regulation that may prove to load business with burdensome cost, constraining rules and regulations that could create a straightjacket smothering creativity, innovation and other improvements. These issues will remain on the research agenda for a long time. In a market driven system such as the one in which European mature corporations operate, the freedom to fail must not be eliminated in our zeal to ensure a clearly transparent system of governance and reporting.

\section{Notes}

This paper was initially elaborated for presentation at The Seventh World Continuous Auditing and Reporting Symposium, March 26/27 th 2004 , Monaco, organised by International University of Monaco, and MAYS Business School at Texas A\&M University. It has progressed according to the valuable comments made and discussion led with academia and practitioners during this presentation. 


\section{References}

Aguilera, R. V. and Jackson, G. (2003). 'The Cross- National Diversity of Corporate Governance: Dimensions and Determinants', The Academy of Management Review, 28, pp. 447 - 465.

Anderson, U., Forsgren, M. and Holm, U. (2002). 'The Strategic Impact of External Networks', Strategic Management Journal, 23, pp. 979 - 996.

Baums, T. and Scott, K. E. (2003). 'Taking Shareholder Protection Seriously? Corporate Governance in the United States and Germany'. Stanford Law and Economics Olin Working Paper No. 272, ECGl - Law Working Paper No. 17/2003.

Baysinger, B.D. and Hoskisson, R.E. (1990). 'The Composition of Boards of Directors and Strategic Controls: Effects on Corporate Strategy', Academy of Management Review, 15, pp. 72 $-87$.

Berglöf, E. (2000). 'Reforming Corporate Governance: Redirecting the European Agenda', in Cohen \& Boyd, Corporate Governance and Globalization: Long Range Planning Issues. Northampton, MA: Edward Elgar.

Berkinshaw, J. and Hood, N. (1998). 'Multinational Subsidiary Evolution: Capability and Charter Change in Foreign-Owned Subsidiary Companies', Academy of Management Review 23 October 1998, pp. 773-795.

Berle, A.A and Means, G.C. (1932). The Modern Corporation and Private Property. Harcourt, Brace \& World Inc; republished (1991) by Transaction Publishers.

Buckley, P.J. and Casson, M. D. (1976). The Future of the Multinational Enterprise. MacMillan: London.

Cernat, L. (2004). 'The emerging European Corporate Governance Model: Anglo-Saxon, Continental, or still the century of diversity?', Journal of European Public Policy, 11 (1), pp.147166.

Cohen, S. and Boyd Ed. (2000). Corporate Governance and Globalization: Long Range Planning Issues. Northampton, MA: Edward Elgar.

Daily, C.M. and Johnson, J.L. (1997). 'Sources of CEO Power and Firm Financial Performance: A Longitudinal Assessment', Journal of Management, 23, pp.97-117.

Dalton, D.C., Daily, C.M., Ellstrand, A.E. and Johnson, J.L. (1998). 'Meta- Analytic Reviews of Board Composition, Leadership Structure, and Financial Performance', Strategic Management Journal, 19, pp. 269-290.

Daly, C. M., Dalton, D. R., Canella, Jr (2003). 'Corporate Governance: Decades of Dialogue and Data', Academy of Management Review, 28, pp. 371-382.

Dalton, D.R., Daily,C. M., Certo, S.T. and Roengoitya, R. (2003). 'Meta-analysis of Financial Performance and Equity: Fusion or Confusion?', Academy of Management Journal, 46, pp. 1326.

Despres, Ch. and Chauvel, D. (2000). Knowledge Horizons - The Present and Promise of Knowledge Management. Oxford: Butterworth-Heinemann.

Dore, R. (2000). Stock Market Capitalism: Welfare Capitalism. Japan and Germany vs AngloSaxons. New York: Oxford University Press. 
Dunning, J.H. (1988). 'The Eclectic Paradigm of International Production: A Restatement and Some Possbile Extensions', Journal of International Business Studies, 19 (March), pp. 1-31.

The Economist (ed.) (2004a). 'Europe's corporate governance. Parma splat: what are the lessons from the scandal at Europe's largest dairy-products group?, The Economist (UK Print edition), 15 January 2004.

The Economist (ed.) (2004b). 'Where's all the fun gone? - Non-executive directors.(The purpose of non-executive directors)', The Economist (US), 20 March 2004.

European KM Forum (2001). 'Towards a common KM framework in Europe'. IST Project No 2000-26393 EKMF Workshop on Common KM framework 2001-11-09v05.doc Final.

Emmons, W.R. and Schmid, F.A. (2000). Corporate Governance and Corporate Performance. Corporate Governance and Globalization: Long Range Planning Issues. Northampton, MA: Edward Elgar, pp. 59-94.

European Industrial Relations Observatory EIRO (2002). Corporate Governance Systems and the Nature of Industrial Restructuring. www.eiro.eurofound.eu.int

FEE European Association of Accountants (2004). OECD Principles of Corporate Governance, re: draft revised text, 10 February 2004

FEE (n.d.). Letters and Statements. www.fee.be

Financial Times (ed.) (2004). 'Understanding Corporate Governance', Financial Times Special Supplement. 23 April 2004, p. 9

Fukao, M. (1995). Financial Integration, Corporate Governance, and the Performance of Multinational Companies. Washington DC: Brookings Institution Press.

Gerlach, M. (2000). Alliance Capitalism. Berkeley: University of California Press.

Grant, R, (1996). 'Towards a Knowledge-based Theory of the Firm'. Strategic Management Journal, 17, pp. 109-122.

Gupta, A.K. and Govindarajan, V.J. (2000). 'Knowledge Flows within Multinational Corporations', Strategic Management Journal, 21, pp. 473 - 496.

Halpern, P. (2000). Systemic Perspectives on Corporate Governance, in Governance \& Globalization, pp.,1-58.

Holmstrom, B. and Kaplan, St. (2003). 'The Dangers of too much Governance', Business Ethics and Public Policy, 45 (1), p. 96.

Hymer, S.H. (1970a). 'The Tasks of Economic History', The Journal of Economic History, 30 (1), pp. 33-50.

Hymer, S.H. (1070b). 'The Efficiency (Contradictions) of Multinational Corporations', Papers and Proceedings of the Eighty-second Annual Meeting of the American Economic Association, The American Economic Review, 60 (2), pp. 441-448.

Jensen, M.C. and Werner, J.B. (1988). 'The Distribution of Power among Corporate Managers, Shareholders, and Directors', Journal of Financial Economics, 3, pp. 305-360.

La Porta, R., Lopez de Silanes, F., Shleifer, A. and Vishny, R. (1998). 'Law and Finance', Journal of Political Economy, 106, pp. 1113-1155. 
Levitt, T. (1983). 'The Globalization of Markets', Harvard Business Review, May - June, pp. 92102.

Lewin, R. (1993). Complexity; Life at the Edge of Chaos. Chicago: University of Chicago Press.

Lynall, M. D., Golden, B.R. and Hillman, A.J. (2003). 'Board Composition from Adolescence to Maturity: A Mutitheoretic View', Academy of Management Review, 28, pp. 416-431.

Martin, R. (1999). Transforming Management in Central and Eastern Europe. Oxford: Oxford University Press.

McKelvey, B. (1999). 'Avoiding Complexity Catastrophe in Coevolutionary pockets: Strategies for Rugged Landscapes', Organizational Science, 10, pp. 294-321.

Muchlinsky, P. (1995). Multinational Enterprise and the Law. Oxford: Blackwell.

O'Sullivan, M. (2000). Contests for Corporate Control: Corporate governance and economic performance in the United States and Germany. New York: Oxford University Press.

Pettigrew, A. (1992). 'On Studying Managerial Elites', Strategic Management Journal, 13, pp. 163-183.

Prahalat, C.K. and Doz, Y. L. (1987). The Multinational Mission: Balancing Local Demands and Global Vision. New York: Free Press.

Rubach, M.J. and Sebora, T. C. (1998). 'Comparative Corporate Governance: Competitive Implications of an Emerging Convergence', Journal of World Business, 33, pp. 167 - 184.

Rugman, A.M. (1981). Inside the Multinationals: The Economics of Internal Markets. New York: Columbia University Press.

Rugman, A.M., Brewer, T.L. (2001). The Oxford Handbook of International Business. Oxford University Press, Oxford.

Rugman, A.M., Verbeke, A. (2004). 'A Perspective on Regional and Global Strategies of Multinational Enterprises', Journal of International Business Studies, 35, pp. 3-18.

Scharpf , F.W. (1997). Games Real Actors Play: Actor-centered Institutionalism in Policy Research. Boulder, CO: Westview.

Shleifer, A. and Vishney, R.W. (1997). 'A Survey of Corporate Governance', Journal of Finance, 52, pp. 737-783.

Shen, W.and Canella, A.A. (2002). 'Power dynamics with top management and their impact on CEO dismissal followed by inside succession', Academy of Management Journal, 45, pp. 11951206.

Spender, J.C. (1996). 'Making Knowledge, the Basis of Dynamic Theory of the Firm', Strategic Management Journal, 17, pp. 45-62.

Spender, J.C. (2002). 'Knowledge Management, Uncertainty and an Emergent Theory of the Firm', in Choo and Bontis (eds), The Strategic Management of Intellectual Capital and Organisational Knowledge. New York: Oxford University Press.

Van der Elst, C. (2000). 'The Equity Markets, Ownership Structures and Control: Towards an International Harmonisation?' , Financial Law Institute, University of Ghent Working Paper, Ghent. 
Wall Street Journal (2004). Untitled. 20 March 2004

Walsh, J.P., Seward, J.K. (1990). 'On the Efficiency of Internal and External Corporate Control Mechanisms', Academy of Management Review,15, pp. 421-458.

Walter, I. (2000). 'Capital Markets and Control of Enterprises in the Global Economy', in Cohen \& Boyd (eds), Corporate Governance and Globalization, Long Range Planning Issues; Northampton, MA: Edward Elgar, pp. 95-128.

Weil, Gotschal, Manges LLP (2002). Comparative Study of Corporate Governance codes relevant to the European Union and its Member states - Executive Summary; www.europa.eu.int.

Wenger, E. (1998). Communities of Practice: Learning, Meaning and Identity. Cambridge: Cambridge University Press. 